\title{
Outbreak of rubella after mass vaccination of children and adult women: challenges for rubella elimination strategies
}

\author{
Ivone Andreatta Menegolla, ${ }^{1}$ Marilina Assunta Bercini, ${ }^{2}$ \\ Maria Tereza Schermann, ${ }^{2}$ Zenaida Marion Alves Nunes, ${ }^{3}$ \\ Teresa Cristina Segatto, ${ }^{4}$ Marilda Mendonça Siqueira, ${ }^{5}$ \\ and Brendan Flannery 6
}

Suggested citation
Menegolla IA, Bercini MA, Schermann MT, Nunes ZMA, Segatto TC, Siqueira MM, et al. Outbreak of
rubella after mass vaccination of children and adult women: challenges for rubella elimination straterubella after mass vaccination of children and adut
gies. Rev Panam Salud Publica. 2011;29(4):243-51.

ABSTRACT Objective. To describe rubella outbreaks and control strategies in the Brazilian state of Rio Grande do Sul before rubella elimination.

Methods. We analyzed rubella and congenital rubella syndrome surveillance data for the state of Rio Grande do Sul and calculated age- and gender-specific incidence of confirmed rubella cases in 2007. We obtained data on measles-rubella doses administered during the outbreak from the state immunization program and reviewed the timing of suspect case notification and implementation of control measures.

Results. Of 2842 confirmed rubella cases reported to the state health department in 2007, $2145(75.5 \%)$ were in males (39.5 cases per 100000 population) and 697 (24.5\%) were in females (12.3 per 100000 population). Incidence among 15- to 39-year-olds was 1.8 to 5.5 times higher in males than in females. Rubella genotype $2 B$ was detected in nasopharyngeal specimens from 13 patients from multiple chains of transmission. Eight children were born with congenital rubella syndrome (5.9 cases per 100000 births in 2008). Delayed notification of initial cases hampered early control efforts, resulting in outbreak spread throughout the state. Rubella transmission was interrupted after mass vaccination of adult men and women as part of a national vaccination campaign.

Conclusions. Routine vaccination strategies and mass vaccination of adolescents and adults for accelerated rubella control and elimination should target men and women.

Key words Rubella; rubella vaccine; disease outbreaks; mass vaccination; Brazil.

National Measles/Rubella Control Program, Ministry of Health, Brasilia, Brazil. Send correspondence to: Ivone Andreatta Menegolla, ivonemenegolla@yahoo.com.br.

2 Department of Epidemiologic Surveillance, Rio Grande do Sul State Health Department, Porto Alegre, Rio Grande do Sul, Brazil.

3 State Public Health Laboratory, Porto Alegre, Rio Grande do Sul, Brazil.
The primary goal of rubella vaccination is to prevent congenital rubella syn-

\footnotetext{
Respiratory and Vaccine Preventable Diseases Surveillance Unit, Secretariat of Health Surveillance, Ministry of Health, Brasilia, Brazil.

5 Laboratory of Measles and Respiratory Viruses, IOC Oswaldo Cruz Foundation, Rio de Janeiro, Brazil.

6 Pan American Health Organization, Brasília, Brazil.
}

drome (CRS), which occurs when susceptible women acquire rubella infection during pregnancy and intrauterine rubella infection damages the developing fetus (1). Preventing the morbidity and complications associated with acquired rubella infection is a secondary 
objective. In Brazil, combined measlesmumps-rubella (MMR) vaccines were introduced into state immunization programs between 1992 and 2000. Catch-up vaccination of children up to 11 years of age rapidly reduced rubella incidence in this age group, but rubella outbreaks affecting mainly young adults occurred throughout Brazil during 1998-2000, with a high incidence of CRS (2-4). With a limited global supply of combined measles-rubella (MR) vaccine, Brazil elected to prioritize CRS control with phased mass vaccination of women of childbearing age against rubella between 1998 and 2002 (5).

Brazil was one of three countries in the Americas (along with Chile and Argentina) that conducted vaccination campaigns among women of childbearing age to accelerate control of CRS; other countries in the region conducted massive rubella vaccination campaigns targeting both male and female adults and adolescents to accelerate control of rubella and CRS $(6,7)$. Although several years of low incidence of rubella followed mass vaccination of women in Brazil, the strategy did not interrupt rubella virus transmission. During 2007-2008, rubella outbreaks were identified throughout Brazil, with the highest incidence among adult males.

To describe rubella outbreaks and control strategies in one of the states most affected by the rubella epidemic in Brazil during 2007-2008, we analyzed immunization and surveillance data from the MR and CRS surveillance systems in the state of Rio Grande do Sul and reviewed the timing and effectiveness of interventions to interrupt rubella virus transmission.

\section{MATERIALS AND METHODS}

The Brazilian state of Rio Grande do Sul has an area of $282062 \mathrm{~km}^{2}$, international borders with Uruguay to the south and Argentina to the west, and a population of 11.1 million (8). In 2010, 85.1\% of the population lived in urban areas (9). The state is administratively divided into 496 municipalities and the health department is organized into 19 regional health districts (10).

\section{Rubella vaccination strategies}

In the state of Rio Grande do Sul, use of rubella-containing vaccines was limited before 1997 when MMR was introduced for children at 1 year of age, with a massive catch-up vaccination campaign that reached an estimated $99.1 \%$ of children 1-12 years old. A second dose of MMR at 4-6 years was added in 2004. Estimated MMR coverage among 1-year-old children was $67.4 \%$ in 1998, fluctuated between $79.8 \%$ and $89.3 \%$ from 1999 to 2002 , and was > 95\% from 2003 through 2007 . Additional catch-up campaigns targeting children 1-4 years of age were conducted in 2000, reaching an estimated coverage of $95.6 \%$, and in 2004 , with $93.8 \%$ coverage of the target age group. In 2002, the state of Rio Grande do Sul conducted a MR vaccination campaign among women of childbearing age (12-39 years old) to accelerate control of CRS (5), reaching an estimated coverage of only $77.3 \%$ of the target population.

\section{Surveillance for rubella and CRS}

Rubella and CRS have been notifiable diseases in the state of Rio Grande do Sul, Brazil, since 1996. Persons presenting to health services with suspected rubella-defined as rash, fever, and lymphadenopathy - or suspected measlesdefined as rash and fever in the presence of cough, coryza, or conjunctivitis-are notified through the National Notifiable Disease System as suspect cases of rubella or measles (11). Suspect cases are investigated by epidemiologic surveillance units in health care facilities or at the municipal or district level. After notification of a suspect case, control measures to prevent secondary cases, including active searches for suspect cases and vaccination of contacts, are instituted as rapidly as possible. Pregnant contacts of confirmed rubella cases are followed up for outcome of pregnancy. For symptomatic contacts and pregnant women recently exposed to case patients with confirmed rubella, blood specimens are collected for serology.

Epidemiologic surveillance units in municipal and regional health departments investigate suspect cases and implement control measures. State health departments assist municipal health departments and partner institutions to disseminate information for health workers and the public, to coordinate outbreak responses throughout the state, and to provide mass vaccination. Measles- and rubella-containing vaccines are provided by the national immunization program.

\section{Enhanced surveillance during rubella outbreaks in 2007}

To identify additional cases of rubella associated with the beginning of the outbreak, the state and municipal health departments jointly conducted a retrospective review of general medicine and pediatric outpatient visits in Pelotas between March and June 2007. For the public health system, 25112 outpatient and 6305 inpatient records were obtained from the billing department of the municipal health department. Records were also obtained for the same period for 2822 outpatient visits at the two largest private 24-hour urgent care centers in Pelotas as well as for 745 hospital admissions at a private hospital for May 2007. A total of 34984 outpatient and inpatient records were reviewed manually for diagnosis of rubella, measles or rash, and fever as well as for laboratory confirmation of rubella infection.

\section{Laboratory methods}

Serum specimens collected from suspect cases are sent to the central state public health laboratory for measles and rubella serology using a commercial rubella $\operatorname{IgM}$ and $\operatorname{IgG}$ enzyme-linked immunosorbent assay (Dade Behring, Marburg, Germany). According to the national surveillance protocol for investigation of measles and rubella outbreaks, nasopharyngeal swabs from individuals with suspected or confirmed rubella were collected only at the beginning of an outbreak in a defined geographic area for confirmation and identification of the etiologic agent. Nasopharyngeal swabs from suspect or confirmed cases were placed in viral transport medium and sent to the national measles and rubella reference laboratory at the Oswaldo Cruz Foundation in Rio de Janeiro for viral isolation or detection and identification of rubella virus by polymerase chain reaction $(12,13)$.

\section{Case definitions}

Laboratory-confirmed cases of rubella are defined as persons testing positive for anti-rubella IgM antibodies (in the absence of recent rubella vaccination) or evidence of a fourfold increase in rubella IgG concentration (international units/ $\mathrm{mL}$ ) in paired sera. Cases lacking laboratory confirmation may be classified as 
clinically confirmed if linked epidemiologically to a laboratory-confirmed case with exposure during the incubation period of the illness. Definitions for suspect, compatible, and confirmed CRS cases and congenital rubella infection are nationally standardized (3).

\section{Data analysis}

Population estimates from the Brazilian Institute of Geography and Statistics (8) were used to calculate the age- and gender-specific incidence of confirmed rubella cases in Rio Grande do Sul in 2007. Odds ratios and $95 \%$ confidence intervals were calculated using Epi Info software (version 6.04d, Centers for Disease Control and Prevention, Atlanta, Georgia, United States of America). The rate of CRS was calculated by dividing the number of confirmed CRS cases born in 2008 by 135 137, the number of registered live births in the state in 2008 (14).

\section{RESULTS}

\section{Rubella outbreaks before 2007}

After the introduction of MMR vaccination for children in the state of Rio Grande do Sul and catch-up vaccination for children aged 1-12 years in 1997, rubella case notifications dropped to low levels with few recognized outbreaks during 2000-2006 (Figure 1). In 2005 and 2006, two rubella outbreaks were identified, with a total of 56 confirmed rubella cases. The first outbreak, which began late in 2005 and ended in 2006, resulted in 50 confirmed rubella cases at a poultry-processing facility, associated with the visit of an industry group from China. Rubella virus genotype $1 \mathrm{j}$ was isolated from five of six patient samples. A total of 10000 employees were followed for clinical signs of rubella in addition to the contacts of 200 suspect rubella cases, and 47274 doses of MR vaccine were administered to adolescent and adult men and women in control activities. Contact tracing identified no additional cases. The second outbreak involved six confirmed rubella cases at a tobacco-processing factory that had relocated one of its units from Rio de Janeiro, where an outbreak of rubella caused by genotype 2B was occurring. Rubella virus was not isolated from nasopharyngeal swabs collected from the cases associated with the tobacco facility. In the second outbreak, 154 suspect cases and their contacts were investigated, and approximately 2000 doses of MR vaccine were administered. A total of 62 women identified as being pregnant during the two outbreaks required follow-up; 58 were employees of the poultry-processing facility who self-identified as being pregnant during control vaccination activities and were not vaccinated. Serum specimens were collected from only two symptomatic, pregnant women; both were in the first trimester of pregnancy and both had confirmed rubella infection. Among 60 women with known out- comes of pregnancy, 2 had spontaneous abortions and 1 delivered a stillborn fetus; 0 of 57 live-born infants had signs or symptoms of CRS. All the live-born infants, including two infants born to mothers with confirmed rubella during pregnancy, were seronegative for rubella IgM antibody at birth.

\section{Rubella outbreaks in 2007}

In April 2007, the state health department was notified by the municipal health department of Pelotas, a city of 323000 inhabitants in the southernmost part of Rio Grande do Sul State, of rubella cases among university students. The region had reported no confirmed cases of rubella since 2003. The first case patient associated with the outbreak was a 16-year-old, unvaccinated male who sought care at a private clinic for suspected dengue fever, and laboratory tests were requested for dengue fever, mononucleosis, and rubella. Only after the clinic received positive results for rubella IgM antibody testing, almost one month after the patient's onset of rash, was the health department notified. Active searches for additional cases among members of the case patient's household and the workplace of the case's father identified four additional IgM-positive cases; two patients were symptomatic and in two patients symptoms had resolved. Control vaccination of household contacts and contacts at the father's workplace was initiated during the week

FIGURE 1. Implementation of rubella control strategies and annual incidence of confirmed rubella cases, Rio Grande do Sul State, Brazil, 1992-2008

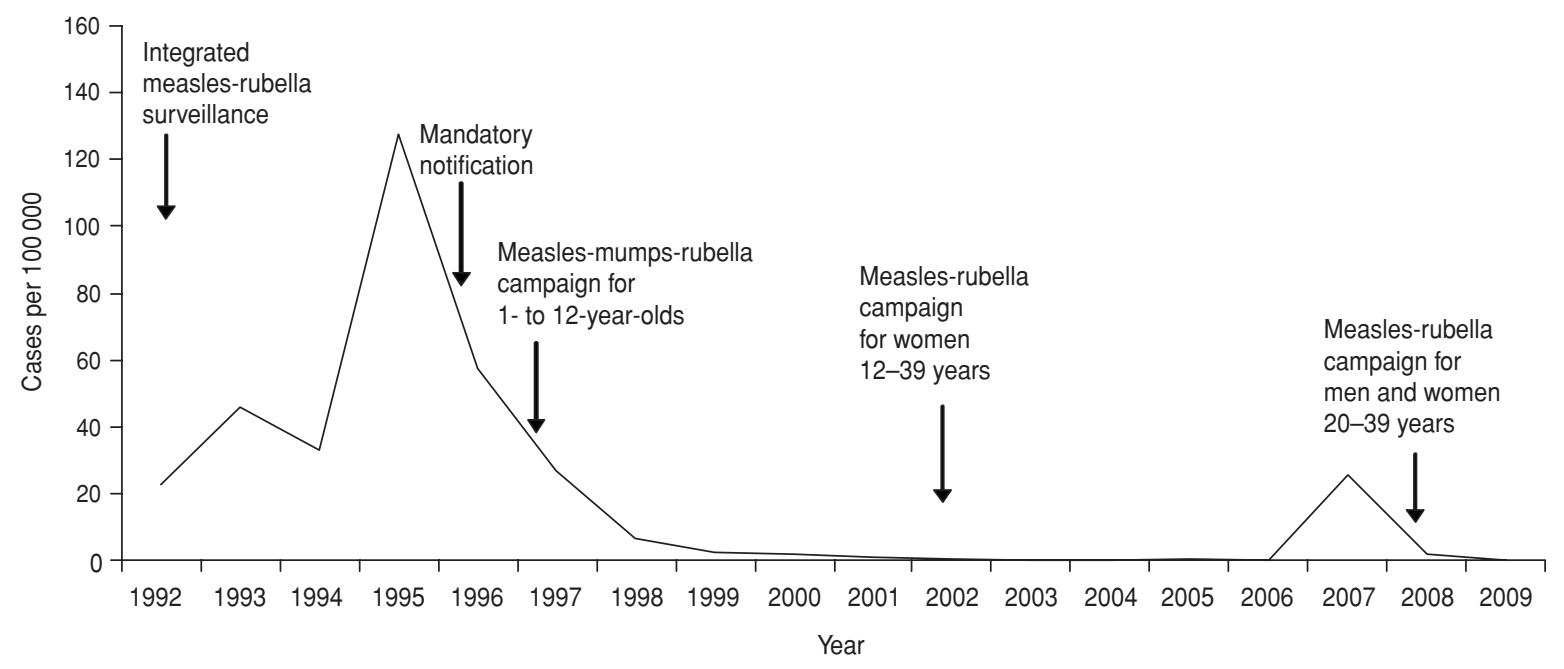


of notification of the initial case. Retrospective review of outpatient and inpatient visits at public and private health care facilities in Pelotas during MarchJune 2007 identified 15 additional confirmed cases of rubella that had not been notified to the state health department, 13 of which were diagnosed at private urgent care centers.

In April 2007, to improve recognition and notification of rubella cases, a health alert was sent to health professionals throughout the state as well as to local and regional media with information about rubella and instructions for notifying suspect cases. The alert sent to health services and resulting media attention led to a sharp rise in notifications of suspect cases during June 2007 (Figure 2). Case investigations and vaccination of known contacts of suspect cases after notification were not able to contain the spread of the outbreak (Figure 3). During June 2007, students at the three largest universities in Pelotas and neighboring Rio Grande, municipalities in the southernmost part of the state, accounted for the majority of confirmed rubella cases (Figure 3b). In July 2007, concurrent with university holidays and a popular, annual festival held in
Pelotas, rubella cases were confirmed in an increasing number of municipalities throughout the state (Table 1, Figure 3c). In August 2007, the state health department conducted mass vaccinations of men and women aged 20 to 39 years, administering approximately 210000 doses of MR vaccine in 22 municipalities of the southern region (Table 1, Figure 2). Although cases peaked in the southern region of the state in September 2007, the number of confirmed rubella cases did not peak throughout the state until November (Figure 3d). In 2008, rubella cases associated with small outbreaks were reported throughout the state from municipalities that had not previously reported cases and had not been targeted for mass vaccination for outbreak control (Table 1).

\section{Outbreak control measures}

From April 2007 through March 2008, more than 700000 doses of measles- and rubella-containing vaccines were administered for outbreak control and localized campaigns, but cases of rubella continued to occur at low levels through 2008. Between January 2007 and November 2008, the state surveillance system classified 3047 suspect cases as rubella: $2384(78.3 \%)$ were laboratory confirmed, $452(14.8 \%)$ were linked to other confirmed rubella cases, and 211 (6.9\%) were clinically compatible cases for which no specimens were available. Of the 3047 episodes classified as rubella, 2842 (93.3\%) occurred from March to December 2007. Nasopharyngeal swabs were collected from individuals with suspected rubella when outbreaks were first notified in different municipalities. Rubella genotype 2B was identified in 13 of 19 nasopharyngeal swabs sent to the national measles and rubella reference laboratory; the remaining 6 were negative for viral detection. The outbreak affected mainly males aged 15 to 39 years, with incidence rates 1.8 to 5.5 times higher than for females of the same age (Table 2); adult men aged 20 to 29 years accounted for $52.7 \%$. There were 198 confirmed rubella episodes among adults 40 years or older, $83.3 \%$ of which were laboratory confirmed. The most frequent clinical symptoms, besides maculopapular rash and fever, included swollen lymph nodes (81.2\% confirmed cases), arthralgia (69.3\%), and conjunctivitis $(65.9 \%)$. Only $7.6 \%$ of male case patients and $11.6 \%$ of females reported

FIGURE 2. Confirmed rubella cases, by month, and timing of mass vaccination for outbreak control and during the national rubella vaccination campaign, Rio Grande do Sul, Brazil, 2007-2008

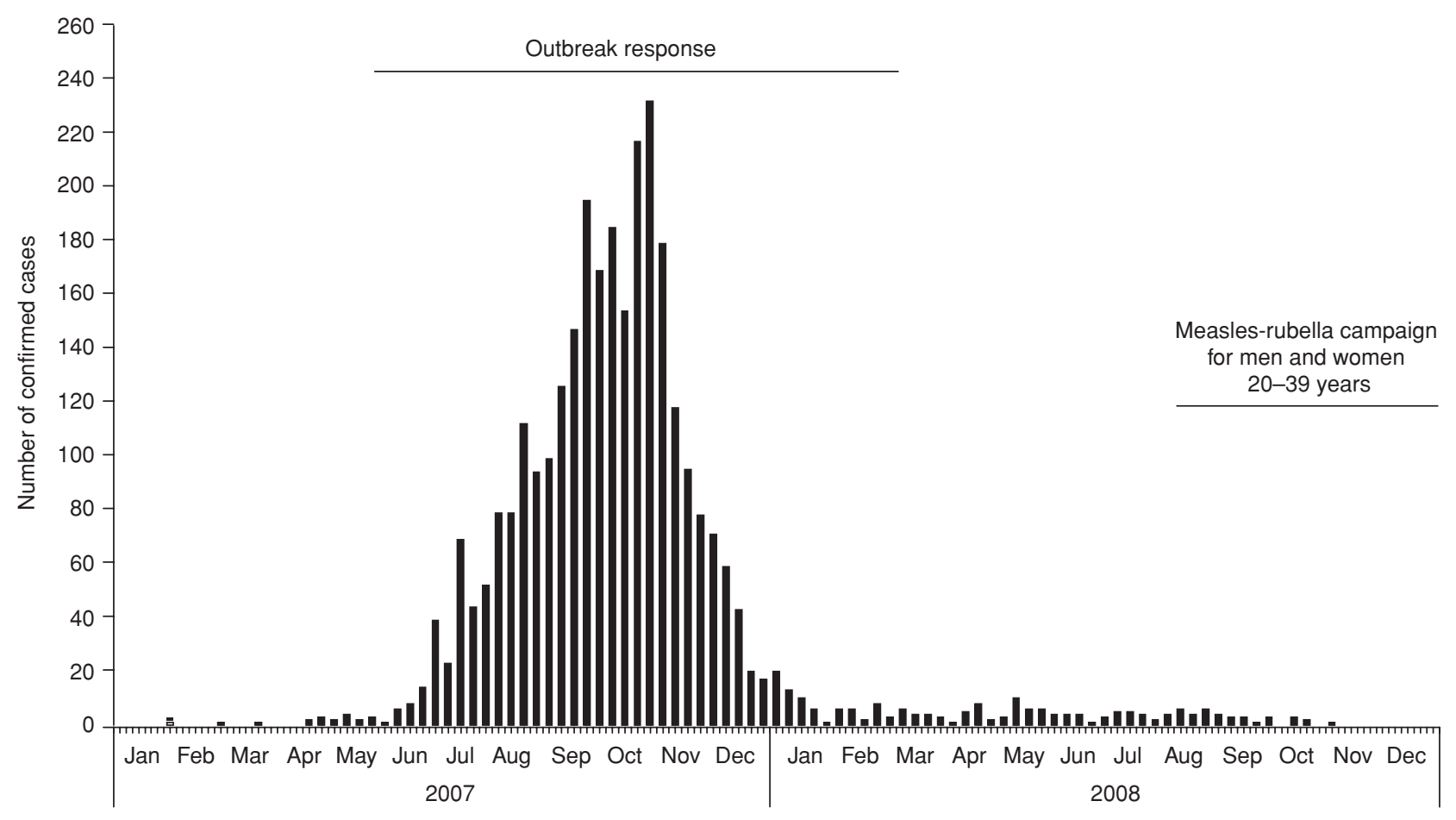



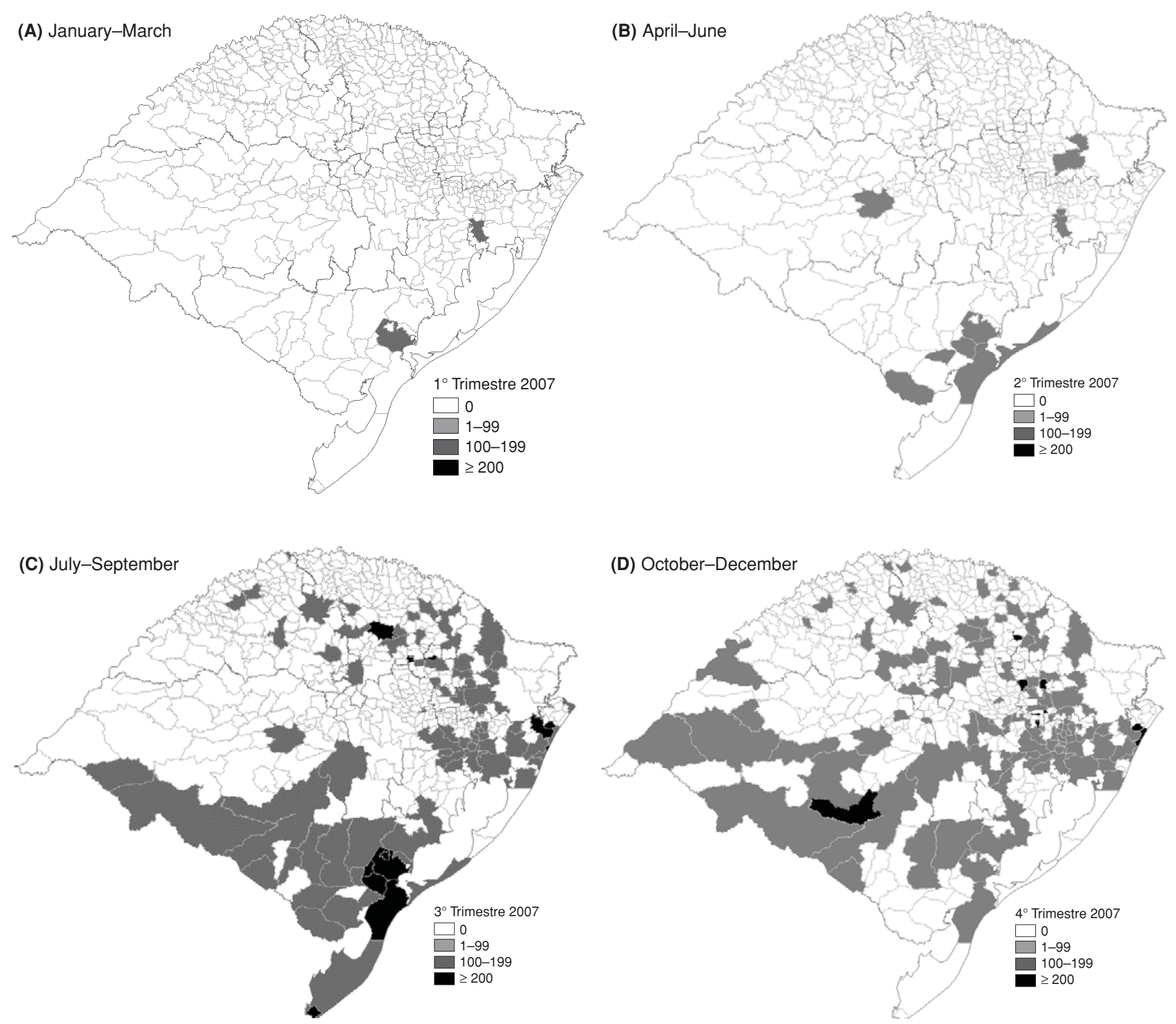

having received the MR or MMR vaccine at some time in the past; $42.6 \%$ of confirmed cases did not know their vaccination status. Of 263 rubella episodes among persons who reported previous vaccination, $184(70.0 \%)$ were confirmed by laboratory testing.

From August through December 2008, as part of a national campaign to eliminate rubella, Rio Grande do Sul administered 3172188 doses of MR vaccine to adult men and women 20 to 39 years of age, reaching an estimated $93.1 \%$ of the target population. The campaign successfully interrupted rubella transmission in the state; the state MR surveillance system has not identified a confirmed rubella case since November 2008.

\section{CRS surveillance}

During the outbreak, the state health department received notification of 132 cases of rubella in pregnant women: 85 in 2007 and 47 in 2008. Of them, 18 $(21.2 \%)$ in 2007 and $6(12.8 \%)$ in 2008 were confirmed based on serology or epidemiologic link to confirmed cases. Upon follow-up, two women reported spontaneous abortion. A total of 8 cases of CRS (5.9 CRS cases per 100000 births in the state in 2008) were associated with the outbreak (Table 3). Mothers of four CRS cases had not been identified as having rubella during pregnancy, although three had contact with confirmed rubella cases at work or home. Six mothers had no history of rubella vaccination. Rubella infection occurred in the first trimester of pregnancy for all those who recalled symptoms of rubella or had laboratory-confirmed rubella infection during pregnancy. Serum specimens collected at birth from all eight CRS cases tested seropositive for rubella IgM anti- 
TABLE 1. Timeline of confirmed cases and control activities, 2005-2009

\begin{tabular}{|c|c|c|c|c|c|c|c|c|c|}
\hline \multirow{3}{*}{$\begin{array}{l}\text { Year and } \\
\text { months }\end{array}$} & \multicolumn{2}{|c|}{ Confirmed rubella cases } & \multirow{2}{*}{\multicolumn{2}{|c|}{$\begin{array}{c}\text { Age of } \\
\text { confirmed cases, years } \\
\end{array}$}} & \multirow{3}{*}{$\begin{array}{l}\text { Number of } \\
\text { municipalities } \\
\text { reporting } \\
\text { confirmed } \\
\text { rubella } \\
\text { cases }\end{array}$} & \multirow{3}{*}{$\begin{array}{c}\text { Number of } \\
\text { rubella } \\
\text { outbreaks }\end{array}$} & \multirow{2}{*}{\multicolumn{2}{|c|}{ Cases per outbreak }} & \multirow{3}{*}{$\begin{array}{l}\text { Number of } \\
\text { vaccine } \\
\text { doses } \\
\text { administered } \\
\text { for rubella } \\
\text { control }^{b}\end{array}$} \\
\hline & \multirow[b]{2}{*}{ Number } & \multirow{2}{*}{$\begin{array}{c}\text { Percent } \\
\text { laboratory } \\
\text { confirmed }\end{array}$} & & & & & & & \\
\hline & & & Median & Range & & & Median & Range & \\
\hline \multicolumn{10}{|l|}{2005} \\
\hline Jan-Dec & 46 & 97.8 & 24 & $0-59$ & $8^{c}$ & 1 & $50^{c}$ & $\mathrm{~N} / \mathrm{A}$ & 73418 \\
\hline \multicolumn{10}{|l|}{2006} \\
\hline Jan-Dec & 13 & 76.9 & 19 & $1-29$ & $14^{d}$ & 1 & 6 & $\mathrm{~N} / \mathrm{A}$ & 75942 \\
\hline \multicolumn{10}{|l|}{2007} \\
\hline Jan-Mar & 2 & 100.0 & 27 & $26-29$ & 2 & 0 & $\mathrm{~N} / \mathrm{A}$ & $N / A$ & 28500 \\
\hline Apr-Jun & 83 & 95.2 & 24 & $0-59$ & 11 & 2 & 35 & $3-67$ & 29951 \\
\hline Jul-Sep & 1307 & 96.2 & 24 & $0-80$ & 94 & 19 & 60 & $10-345$ & 304646 \\
\hline Oct-Dec & 1455 & 91.3 & 25 & $0-69$ & 119 & 25 & 48 & $10-664$ & 284253 \\
\hline \multicolumn{10}{|l|}{2008} \\
\hline Jan-Mar & 85 & 90.6 & 26 & $0-59$ & 24 & 6 & 11 & $4-21$ & 45966 \\
\hline Apr-Jun & 57 & 89.5 & 28 & $0-59$ & 13 & 3 & 7 & $7-31$ & 25973 \\
\hline Jul-Sep & 49 & 85.7 & 25 & $0-59$ & 28 & 3 & 6 & $4-11$ & 2442369 \\
\hline Oct-Dec & 9 & 44.4 & 29 & $5-59$ & 11 & 0 & $\mathrm{~N} / \mathrm{A}$ & $\mathrm{N} / \mathrm{A}$ & 799822 \\
\hline \multicolumn{10}{|l|}{2009} \\
\hline Jan-Dec & 0 & & $\mathrm{~N} / \mathrm{A}$ & & 0 & 0 & $\mathrm{~N} / \mathrm{A}$ & $\mathrm{N} / \mathrm{A}$ & 32923 \\
\hline Total & & & & & & & & & 4143763 \\
\hline $\begin{array}{l}\text { Note: N/A: no } \\
\text { a Outbreaks d } \\
{ }^{b} \text { Doses of me } \\
{ }^{c} \text { Includes five } \\
{ }^{d} \text { Includes fou } \\
\text { palities that }\end{array}$ & $\begin{array}{l}\text { No or more } \\
\text { Ila or measl } \\
\text { ties with rub } \\
\text { ities with ru } \\
\text { oradic rubell }\end{array}$ & $\begin{array}{l}\text { la cases linkec } \\
\text { umps-rubella v } \\
\text { cases linked to } \\
\text { cases linked t } \\
\text { es. }\end{array}$ & $\begin{array}{l}\text { chain of tr } \\
\text { nes adminis } \\
\text { outbreak ir } \\
\text { outbreak }\end{array}$ & $\begin{array}{l}\text { sion. } \\
\text { Fundo, R } \\
\text { Fundo, o }\end{array}$ & $\begin{array}{l}\text { years of age in } \\
\text { ide do Sul, and } \\
\text { nicipality with ruk }\end{array}$ & $\begin{array}{l}\text { c control and } \\
\text { k-associated } \\
\text { ses linked to }\end{array}$ & campai & $\begin{array}{l}\text { oms in } 2 \\
\text { Cachoie }\end{array}$ & nd nin \\
\hline
\end{tabular}

TABLE 2. Confirmed rubella cases, by age and gender, Rio Grande do Sul, Brazil, 2007

\begin{tabular}{|c|c|c|c|c|c|c|c|c|}
\hline \multirow[b]{2}{*}{ Age, years } & \multicolumn{3}{|c|}{ Male } & \multicolumn{3}{|c|}{ Female } & \multirow[b]{2}{*}{ Relative risk } & \multirow[b]{2}{*}{$\begin{array}{c}95 \% \text { confidence } \\
\text { interval }\end{array}$} \\
\hline & Population & $\begin{array}{l}\text { Number } \\
\text { of cases }\end{array}$ & $\begin{array}{c}\text { Incidence per } \\
100000\end{array}$ & Population & $\begin{array}{l}\text { Number } \\
\text { of cases }\end{array}$ & $\begin{array}{c}\text { Incidence per } \\
100000\end{array}$ & & \\
\hline$<1$ & 72997 & 44 & 60.3 & 69619 & 38 & 54.6 & 1.10 & $0.72, \quad 1.70$ \\
\hline $1-4$ & 325884 & 25 & 7.7 & 310967 & 22 & 7.1 & 0.72 & $0.43, \quad 1.22$ \\
\hline $5-9$ & 447646 & 21 & 4.7 & 429240 & 18 & 4.2 & 1.12 & $0.60, \quad 2.10$ \\
\hline $10-14$ & 456470 & 44 & 9.6 & 439604 & 37 & 8.4 & 1.15 & $0.74, \quad 1.77$ \\
\hline $15-19$ & 468315 & 174 & 37.2 & 452133 & 91 & 20.3 & 1.83 & $1.42, \quad 2.35$ \\
\hline $20-29$ & 958632 & 1498 & 156.3 & 939264 & 265 & 28.2 & 5.54 & $4.86, \quad 6.31$ \\
\hline $30-39$ & 780840 & 266 & 34.1 & 800924 & 101 & 12.6 & 2.70 & $2.15, \quad 3.40$ \\
\hline $40-49$ & 764015 & 60 & 7.9 & 814242 & 70 & 8.6 & 0.91 & $0.65, \quad 1.29$ \\
\hline $50-59$ & 573434 & 11 & 1.9 & 625797 & 49 & 7.8 & 0.24 & $0.13, \quad 0.47$ \\
\hline$\geq 60$ & 578641 & 2 & 0.3 & 771653 & 6 & 0.8 & 0.44 & $0.09, \quad 2.20$ \\
\hline Total & 5426874 & 2145 & 39.5 & 5653443 & 697 & 12.3 & 1.55 & $0.10,24.71$ \\
\hline
\end{tabular}

TABLE 3. Cases of congenital rubella syndrome and congenital infection associated with rubella outbreak in Rio Grande do Sul, Brazil, 2007-2008: child and maternal characteristics

\begin{tabular}{|c|c|c|c|c|c|c|c|c|}
\hline \multirow[b]{2}{*}{$\begin{array}{c}\text { Case } \\
\text { number }\end{array}$} & \multicolumn{3}{|c|}{ Child characteristics } & \multicolumn{5}{|c|}{ Maternal characteristics } \\
\hline & $\begin{array}{c}\text { CRS and } \\
\text { congenital } \\
\text { infection }\end{array}$ & $\begin{array}{l}\text { Laboratory } \\
\text { confirmation }\end{array}$ & $\begin{array}{c}\text { Birth } \\
\text { month } \\
\text { and year }\end{array}$ & $\begin{array}{c}\text { Mother's } \\
\text { age, } \\
\text { years }\end{array}$ & $\begin{array}{c}\text { Rubella } \\
\text { infection or } \\
\text { exposure }\end{array}$ & $\begin{array}{c}\text { Trimester } \\
\text { of pregnancy }\end{array}$ & $\begin{array}{c}\text { Prior } \\
\text { rubella } \\
\text { vaccination }\end{array}$ & $\begin{array}{l}\text { Reason for } \\
\text { no prior } \\
\text { vaccination }\end{array}$ \\
\hline 1 & CRS & $\lg M_{+}$ & Feb 2008 & 26 & Contact at work & 1 & No & Pregnant during 2002 campaign \\
\hline 2 & CRS & $\lg \mathrm{M}_{+}$ & Mar 2008 & 27 & Epi linked & Unknown & Yes $^{a}$ & $\mathrm{~N} / \mathrm{A}$ \\
\hline 3 & CRS & $\lg M_{+}$ & Apr 2008 & 21 & Lab confirmed & 1 & No & Unaware of disease and vaccine \\
\hline 4 & CRS & $\lg M_{+}$ & May 2008 & 26 & Contact at work & 1 & No & Afraid of injection \\
\hline 5 & CRS & $\lg \mathrm{M}_{+}$ & Apr 2008 & 18 & Contact at home & 1 & No & Afraid of injection \\
\hline 6 & CRS & $\lg M_{+}$ & Aug 2008 & 16 & Lab confirmed & 1 & No & Unaware of disease and vaccine \\
\hline 7 & CRS & $\lg \mathrm{M}_{+}$ & Oct 2008 & 39 & Unknown & Unknown & Yes $^{a}$ & $\mathrm{~N} / \mathrm{A}$ \\
\hline 8 & CRS & $\lg \mathrm{M}_{+}$ & Apr 2008 & 16 & Lab confirmed & 1 & No & Unknown \\
\hline
\end{tabular}

Note: CRS: congenital rubella syndrome, N/A: not applicable.

a Verbal report (undocumented) of receipt of measles-rubella vaccine during mass vaccination of women 12-39 years old in 2002. 
bodies; four nasopharyngeal swabs tested positive by reverse transcriptase polymerase chain reaction for the presence of rubella virus genotype $2 \mathrm{~B}$, while 4 were negative for the presence of rubella virus.

\section{DISCUSSION}

The outbreak of rubella in the state of Rio Grande do Sul, Brazil, highlights several challenges for rubella control in settings that have successfully lowered disease incidence by introducing rubella vaccination. Following a period of low incidence of rubella in the state, private health providers failed to notify suspect rubella cases, possibly because there was a low index of suspicion for rubella or minimal experience with notifying suspect cases. Delay in notification of initial cases and clusters resulted in missed opportunities for implementing control measures. There were many indicators that only a small proportion of rubella cases were notified, including the large number of unreported, confirmed rubella cases identified in retrospective review of medical records and the high percentage of cases that reported arthralgia. With the substantial proportion of asymptomatic rubella infections, control strategies focused on a small percentage of suspect cases are unlikely to contain transmission.

Susceptibility to rubella among young adult men sustained rubella virus transmission throughout Brazil in 2007, which resulted in numerous CRS cases (15). Rubella epidemics in Australia (16), United Kingdom (17), Austria (18), and Croatia (19) have demonstrated that unvaccinated males play a role in sustaining rubella transmission and in rubella outbreaks, inevitably exposing some pregnant women and resulting in preventable cases of CRS. Outbreaks in Brazil occurred simultaneously with rubella outbreaks in Chile and Argentina (20). These three countries, which originally targeted adult and adolescent women for mass vaccination, accounted for $98 \%$ of rubella cases notified in the Americas in 2007 and 2008 (7). Reactive vaccination strategies in these three countries did not stop the spread of rubella virus. To accelerate elimination of rubella and CRS, Chile and Argentina conducted vaccination campaigns targeting adult men in 2007 and 2008, respectively, and Brazil conducted a national rubella vaccination campaign targeting men and women in 2008. In
2000, a limited global supply of MR vaccine meant that Brazil had to conduct vaccination campaigns among women of childbearing age in phases; including the male population would have delayed campaigns to prevent CRS cases. By 2008, the global supply of MR vaccine had improved, making it possible for Brazil to conduct a national rubella vaccination campaign targeting 70 million men and women (21).

Although delays in identifying and notifying initial cases hampered control measures in Rio Grande do Sul, the rubella epidemic that affected Brazil in 2007 would likely have reached the state even if the initial cases had been rapidly notified and contained. Importations from other states in Brazil that were experiencing outbreaks among university students would have been likely, as this population is highly mobile and has been associated with outbreaks of infectious diseases, including a resurgence of mumps in the United States (22). The rubella outbreak in Rio Grande do Sul was associated with circulation throughout Brazil, Chile, and Argentina of rubella genotype 2B $(7,15,20)$. In 2007 and 2008, the national measles and rubella reference laboratory identified genotype $2 B$ from samples collected from rubella outbreaks in multiple states in Brazil (23).

While the incidence of rubella in adult women during the 2007 outbreak was lower than that among men, selective vaccination of women in 2002 failed to prevent additional CRS cases as a result of low vaccination coverage (77.3\%). Adult women had higher reported rates of rubella than young children during the 2007 outbreak, reflecting higher vaccination coverage among children than among adult women. Heightened awareness of CRS and better notification of suspect cases likely contributed to improved sensitivity of CRS surveillance in Rio Grande do Sul in 2008 than during previous rubella outbreaks, resulting in larger numbers of confirmed CRS cases. The rate of confirmed cases of CRS, 5.9 cases per 100000 live births, in Rio Grande do Sul in 2008 was higher than the incidence of CRS identified in Brazil after rubella outbreaks in 2000 in which more than 15000 confirmed rubella cases were identified (2). The experience reinforced the importance of achieving high and homogeneous vaccination coverage in mass campaigns to avoid leaving pockets of susceptible women at risk.
The cost for the state and municipal health department of control activities and vaccination was estimated at more than US\$1 million. This estimate does not include the long-term costs for the care of children born with CRS (24), nor does it include the cost of health care utilization during the outbreak or of lost productivity. A study conducted during a rubella outbreak in the northeastern city of Fortaleza, Brazil, in 2007 estimated direct medical costs of US\$51 per rubella infection and indirect costs including missed work of US\$357 per episode. ${ }^{7}$ For confirmed cases alone, these estimated costs for medical care and lost productivity add more than US\$1 million to the estimated financial impact of the rubella outbreak in Rio Grande do Sul.

Surveillance data have limitations. Reported cases represent only those symptomatic episodes for which medical attention was sought that met the surveillance case definition and for which health professionals suspected measles or rubella. Children and women of childbearing age may be more likely to present for medical attention and episodes among them may be more likely to be reported. Complications of rubella infection during pregnancy, including abortion and fetal death, are not captured without active follow-up, which was inconsistent. Population estimates from the national census may be inaccurate for highly mobile populations, such as university students. However, surveillance data provide information about the age- and gender-specific distribution of cases that were useful for implementation and evaluation of control measures during the 2007 rubella outbreak. The occurrence of laboratory-confirmed rubella infections among persons born before the introduction of rubella vaccination suggests that these individuals had not been previously exposed to rubella virus, consistent with serologic data from other Brazilian states $(25,26)$.

Experience in the Americas adds to the growing body of evidence that mass vaccination to accelerate control and elimination of rubella should target adolescent and adult men and women. The success of mass vaccination of adult and adolescent men and women for accelerating

\footnotetext{
Mota DM, Beltrão HM, Lanzieri TM, Vieira LC, Machado M. Avaliação econômica da rubéola e de estratégia de controle em situação de surto em Fortaleza (Ceará), Brasil, 2007. Saúde e Sociedade, in press.
} 
control and elimination of rubella led member states of the Pan American Health Organization in 2003 to adopt a rubella elimination goal $(6,27)$. Rubella surveillance data for the Americas suggest that endemic transmission of rubella has been interrupted (28); the last confirmed cases of rubella in Brazil had onset of symptoms in December 2008. Prompt identification and notification of imported rubella cases and rapid response are required to maintain rubella elimination in the Americas. As more regions move toward rubella control and elimination goals, countries need to understand the risks and benefits of the strategies they choose and not be lulled into a false sense of security by selective vaccination strategies that do not achieve high and homogeneous coverage.

Acknowledgments. Several individuals provided invaluable assistance during the 2007 rubella epidemic, including Maria Salet Parise, Fabiano Marques Rosa, and Silvia Silva. Susan Reef provided helpful comments to improve the manuscript. We thank all the professionals in the immunization programs and epidemiologic surveillance departments of the regional and municipal health departments of Rio Grande do Sul, especially the teams in Rio Grande, Pelotas, Porto Alegre, Cachoeirinha, and Passo Fundo and their directors Clarice Dalla Vechia, Maria Regina Freitas, Adelaide Postai, Rosane Gralha, Tânia Rabio, and Mara Dill. The measlesrubella surveillance system, case investigation, rubella control strategies, and vaccination activities were funded by the Rio Grande do Sul State Health Department and the Brazilian Ministry of Health.

\section{REFERENCES}

1. Plotkin SA, Reef S. Rubella vaccine. In: Plotkin SA, Orenstein WA, Offit PA, eds. Vaccines, 5th ed. Philadelphia, PA: WA Saunders Co; 2008. Pp. 737-72.

2. Lanzieri TM, Parise MS, Siqueira MM, Fortaleza BM, Segatto TC, Prevots DR. Incidence, clinical features and estimated costs of congenital rubella syndrome after a large rubella outbreak in Recife, Brazil, 1999-2000. Pediatr Infect Dis J. 2004;23(12):1116-22.

3. Lanzieri TM, Prevots DR, Dourado I. Surveillance of congenital rubella syndrome in Brazil, 1995-2005. J Pediatr Infect Dis. 2007; 2:15-22.

4. Lanzieri TM, Segatto TC, Siqueira MM, de Oliviera Santos EC, Jin L, Prevots DR. Burden of congenital rubella syndrome after a community-wide rubella outbreak, Rio Branco, Acre, Brazil, 2000 to 2001. Pediatr Infect Dis J. 2003;22(4):323-9.

5. Pan American Health Organization. Brazil accelerates control of rubella and prevention of congenital rubella syndrome program. EPI Newsl. 2002;24:1-3.

6. Morice A, Ulloa-Gutierrez R, Avila-Aguero ML. Congenital rubella syndrome: progress and future challenges. Expert Rev Vaccines. 2009;8(3):323-31.

7. Centers for Disease Control and Prevention. Progress toward elimination of rubella and congenital rubella syndrome-the Americas, 2003-2008. MMWR Morb Mortal Wkly Rep. 2008;57(43):1176-9.

8. Instituto Brasileiro de Geografia e Estatística. Projeção da População do Brasil por sexo e idade: 1980-2050-Revisão 2004. 2007. Available from: ftp://ftp.ibge.gov.br/Estimati vas_Projecoes_Populacao/. Accessed 30 April 2010.

9. FEEDADOS. Demografia/Taxa de urbanização-2006. 2010. Available from: http:// www.fee.tche.br/feedados/consulta/sel_mo dulo_pesquisa.asp. Accessed 30 April 2010.

10. Pan American Health Organization. Health situation in the Americas 2007: basic indicators. Washington, DC: PAHO; 2007. CDR Rev. 1997;7(2):R26-32.
11. Ministry of Health. Confirmed cases of rubella, Brazil and regions, 1997-2006. Brasilia, Brazil: Ministry of Health; 2007.

12. Bosma TJ, Corbett KM, O'Shea S, Banatvala JE, Best JM. PCR for detection of rubella virus RNA in clinical samples. J Clin Microbiol. 1995;33(5):1075-9.

13. Donadio FF, Siqueira MM, Vyse A, Jin L, Oliveira SA. The genomic analysis of rubella virus detected from outbreak and sporadic cases in Rio de Janeiro state, Brazil. J Clin Virol. 2003;27(2):205-9.

14. Rio Grande do Sul State Health Department. Estatisticas de nascimento. 2010. Available from: http:/ /www.saude.rs.gov.br/wsa/ portal/index.jsp?menu=organograma\&cod= 746. Accessed 30 April 2010.

15. Segatto C, Samad S, Serrate Mengue S, Rodrigues G, Flannery B, Toscano CM. Historical analysis of birth cohorts not vaccinated against rubella prior to national rubella vaccination campaign, Brazil. J Infect Dis. Forthcoming 2011.

16. Sullivan EM, Burgess MA, Forrest JM. The epidemiology of rubella and congenital rubella in Australia, 1992 to 1997. Commun Dis Intell. 1999;23(8):209-14.

17. Miller E, Waight P, Gay N, Ramsay M, Vurdien J, Morgan-Capner P, et al. The epidemiology of rubella in England and Wales before and after the 1994 measles and rubella vaccination campaign: fourth joint report from the PHLS and the National Congenital Rubella Surveillance Programme. Commun Dis Rep

18. Schmid D, Kasper S, Kuo HW, Aberle S, Holzmann H, Daghofer E, et al. Ongoing rubella outbreak in Austria, 2008-2009. Euro Surveill. 2009;14(16).

19. Bakasun V, Suzanic-Karnincic J. A rubella outbreak in the region of Rijeka, Croatia. Int J Epidemiol. 1995;24(2):453-6.

20. Valinotto LE, Viegas M, Acevedo ME, Barrero PR, Mistchenko AS. Phylogenetic analysis of rubella viruses isolated in 2008 outbreak in Argentina. J Clin Virol. 2009;46(3):286-9.
21. Pan American Health Organization. Brazil: vaccination campaign to eliminate rubella. EPI Newsl. 2009;31(2):1-4.

22. Dayan GH, Quinlisk MP, Parker AA, Barskey AE, Harris ML, Schwartz JM, et al. Recent resurgence of mumps in the United States. N Engl J Med. 2008;358(15):1580-9.

23. Icenogle J, Siqueira M, Abernathy E, Lemos XR, Fasce RA, Torres G, et al. Virologic surveillance for wild-type rubella viruses in support of elimination of rubella in the Americas. J Infect Dis. Forthcoming 2011.

24. Irons B, Lewis MJ, Dahl-Regis M, CastilloSolorzano C, Carrasco PA, de Quadros CA. Strategies to eradicate rubella in the Englishspeaking Caribbean. Am J Public Health. 2000;90(10):1545-9.

25. Inagaki AD, Oliveira LA, Oliveira MF, Santos RC, Araújo RM, Alves JA, et al. Soroprevalência de anticorpos para toxoplasmose, rubéola, citomegalovírus, sífilis e HIV em gestantes sergipanas. Rev Soc Bras Med Trop. 2009;42(5):532-6.

26. Zanetta DM, Cabrera EM, Azevedo RS, Burattini MN, Massad E. Seroprevalence of rubella antibodies in the state of Sao Paulo, Brazil, 8 years after the introduction of vaccine. Vaccine. 2003;21(25-26):3795-800.

27. Castillo-Solorzano C, Carrasco P, Tambini G, Reef S, Brana M, de Quadros CA. New horizons in the control of rubella and prevention of congenital rubella syndrome in the Americas. J Infect Dis. 2003;187(Suppl 1):S146-52.

28. Pan American Health Organization. Monthly distribution of confirmed rubella cases, the Americas, 2008-2009. Measles/Rubella Wkly Bull. 2010;16(6).

Manuscript received on 20 August 2010. Revised version accepted for publication on 3 February 2011. 
RESUMEN Objetivo. Describir los brotes de rubéola y las estrategias para el control de la enfermedad anteriores a la eliminación de la rubéola en el estado brasileño de Rio Grande do Sul.

\section{Brote epidémico de rubéola tras la vacunación masiva de niños y mujeres adultas: un reto para las estrategias de eliminación de la rubéola}

Métodos. Se analizaron los datos de vigilancia epidemiológica sobre la rubéola y el síndrome de rubéola congénita del estado de Rio Grande do Sul y se calculó la incidencia específica por edad y sexo de los casos confirmados de rubéola en el 2007. A partir del programa de vacunación estatal se obtuvieron datos sobre las dosis de vacunación antisarampionosa y antirrubeólica administradas durante el brote y se analizaron el momento de notificación de los casos sospechosos y la puesta en práctica de medidas de control.

Resultados. De los 2842 casos confirmados de rubéola notificados al departamento de salud estatal en el 2007, $2145(75,5 \%)$ correspondieron a hombres (39,5 casos por 100000 habitantes) y $697(24,5 \%)$ a mujeres (12,3 por 100000 habitantes). La incidencia en las personas de 15 a 39 años de edad fue de 1,8 a 5,5 veces mayor en los varones que en las mujeres. En 13 pacientes provenientes de distintas cadenas de transmisión se detectó el genotipo 2B del virus de la rubéola en muestras obtenidas de la nasofaringe. Nacieron 8 niños con síndrome de rubéola congénita (5,9 casos por 100000 nacimientos en el 2008). La demora en la notificación de los casos iniciales obstaculizó la adopción temprana de medidas de control, lo que hizo que el brote se propagara a todo el estado. La transmisión de la rubéola se interrumpió después de la vacunación masiva de varones y mujeres adultos como parte de una campaña nacional de vacunación.

Conclusiones. Las estrategias de vacunación sistemática y la vacunación masiva de adolescentes y adultos tendientes a acelerar el control y la eliminación de la rubéola deben dirigirse tanto a varones como a mujeres.

Palabras clave Rubéola (sarampión alemán); vacuna contra la rubéola; brotes de enfermedades; vacunación masiva; Brasil. 